\title{
POLITIK, AGAMA DAN NEGARA: PEMERINTAHAN ISLAM DI MALAYSIA
}

\author{
Ismail Suardi Wekke \\ Sekolah Tinggi Agama Islam Negeri (STAIN) Sorong, Papua Barat. \\ Email: iswekke@gmail.com
}

Abstract

in mainstream discourse always separate on religion and state. In addition, this perspective arouses when there was a conflict between church and government ruler in the past. Therefore, it is a need to explore in the Muslim country bow the relation between religions in this context is Islam and the state on the other side. This research was conducted in Malaysia to discover implementation of Islam as spirits of government in realizing their dream as nation. Qualitative research approach employed to discover data. In-depth interview and observation were employed in collecting data. During interview and abservation, guidelines were utilized as instrument. This study shows that Islam is maintain the character of govermment official since the state was founded. Moreover, in the time of governing they extend the religion principle to enhance the administration activities. Finally, this research concludes that Islam and nation can coexist to expand the organization in politics.

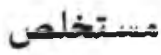

ليس من الصحيح ان الدولة بدون الدين ف.قط. ولكن الدين والدولة من الفقرة. احد من الدون الحال التي تجرى بالحكومية الإسلامية هي مالزبا. لذلك، هذ البحث يجرى بالمنئكلات لأن يرى كيفـ، الدولة الإسلامية تطبق العناصر في مهمة وكيفيات العامة. استخدهم الباحث تصشيم

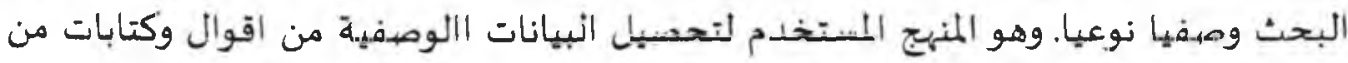
الملانحظة وكذلك معرفة نتائج من المحادئة. وأجريت عملية النقكير في نهاية كل دورة. وهناك ادوات اخرى اضافية مثل دليل المقابلة ودليل الملاحظة والوئائق. تتكون طريقة جمع المعلومات من المقابلة والملاحظة والإستباتة والوثائق. من المهمة ان الوظائف القاعدية تتجه لدى الولاية. 


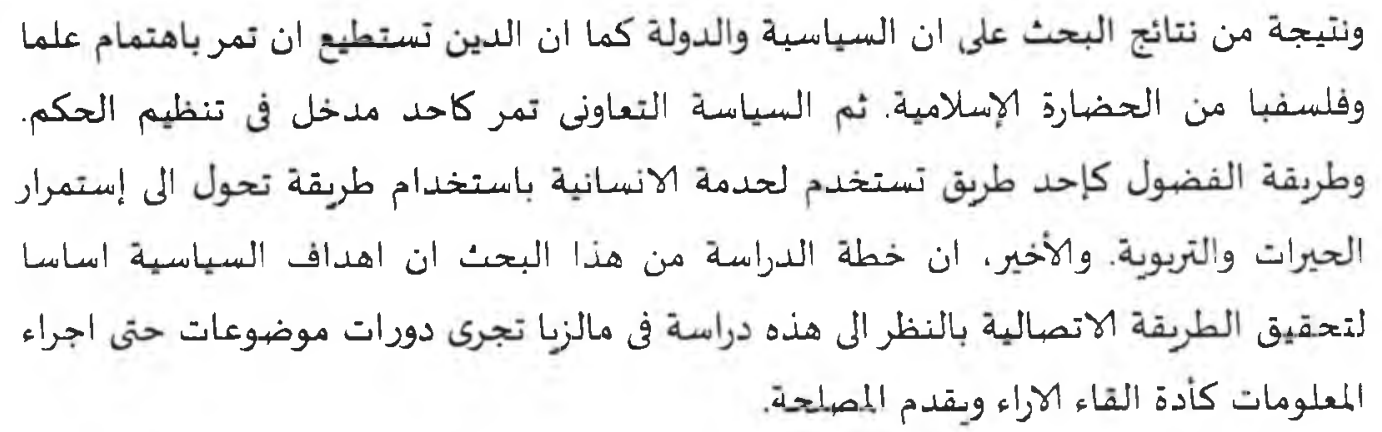

Keywords. pemerintahan Islam, Malaysia, aganıa, negara, tata kelola

\section{A. Pendahuluan}

Di antara negara-negara dunia tidak banyak yang menjadikan agama sebagai kesatuan dalam kelembagaan pemerintahan. Praktik umum yang ada seperti Amerika Serikat adalah memisahkan antara agama dan negara. Walaupun secara tidak tegas penyatuan antara agama dan negara, selalu saja dapat dilihat adanya pengaruh agama terhadap konstitusi negara, diantaranya Filipina. Mayoritas warga menganut Kristen sehingga dikonstruksilah aturan kenegaraan yang melarang perceraian. Ini berasal dari spirit keagamaan bahwa pernikahan hanya dilaksanakan sekali seumur hidup. Ini dapat diduga bahwa mendapatkan pengaruh dari prinsip keagamaan. Sementara di sisi lain, ada Malaysia yang secara nyata melembagakan Islam sebagai agama resmi negara. Selanjutnya menjadikan prinsip-prinsip Islam sebagai dasar kenegaraan. Dipandang dari teori sosial, ini kemudian dinamakan dengan sumber stabilitas politik. ${ }^{1}$

Selanjutnya, operasionalisasi negara diselenggarakan dengan sistem pemerintahan. Ada bagian-bagian negara yang saling berhubungan dan mempunyai ketergantungan dengan fungsi yang secara keseluruhannya. Satu bagian saja yang tidak bekerja maka akan menimbulkan dampak bagi unit yang lain dalam proses menjalankan fungsi negara. Mungkin saja akan terganggu atau

1 Charles Y. Glock, "Images of God, Images of Man, and The Organization of Social Life", dalam Joumal for the Scientific Siudly of Religion, No. 11 (1972), hal. 1-15. 
Hubungan keduanya dijelaskan Michael Saward bahwa ada penggunaan "unit politik" sehingga akan mempengaruhi entitas secara geografi." Dalam melaksanakan suatu prinsip jika ini kemudian disebut sebagai politik, maka ada prosedur dan persyaratan yang berada dalam lingkungan itu sebelum memenuhi kondisi yang diinginkan. Hanya saja perlu diingat bahwa ketika melaksanakan prinsip, maka nilai yang ada dalam pandangan individu serta merta akan mengikut kedalam prinsip yang akan dilaksanakan.

Dengan demikian, agama yang menjadi pegangan individu dalam komunitas merupakan salah satu prinsip yang menjadi acuan. Ini akan terefleksi dalam bentuk interpretasi untuk menyelenggarakan tata kelola dalam kelompok tersebut. Sejalan dengan pandangan Arkoun bahwa selama ini agama hanya menjadi nalar teologis yang hanya berlaku dalam konteks pengagungan Allah. ${ }^{8}$ Sementara agama juga diperlukan untuk menelaah hal-hal yang berhubungan dengan masalah kemanusiaan. Selanjutnya Arkoun menjelaskan bahwa seharusnya agama itu peduli pada pembangunan tata moral dan lingkungan. Agama harus wujud dalam bentuk manfaat kemanusiaan dalam arti yang luas. Tidak sebatas ritual saja tetapi harus juga melembaga di luar aktivitas penyembahan. Karena apapun yang dilakukan dalam prosesi ritual yang ada itu semata-mata untuk kebutuhan manusia. Sama sekali tidak ada terkait dengan Allah. Sehingga, dampak kebajikan sosial harus ada dalam kehidupan seharihari.

Bagi Ibnu Khaldun politik justru sesuatu yang mulia.' Sehingga tidak perlu ditolak dan dikategorikan sebagai hal yang kotor. ${ }^{10}$ Justru, manusia hanya satu-satunya makhluk yang memiliki sistem politik dan kehidupan bernegara. Maka cara untuk menghadapinya dengan memunculkan sikap terbaik manusia yaitu moralitas yang tinggi disertai dengan kehidupan keagamaan yang luhur.

${ }^{7}$ Michael Saward, "Democracy and Competing Values", dalam Government and Opposition, Vol. 31, No. 4. (1996), hal. 467-86.

${ }^{8}$ Mohammed Arkoun, Islam Kontemporer. Menuju Dialog Antar-ugama, (Yogyakarta: Pustaka Pclajar, 2001).

${ }^{9}$ A Rahman Zainuddin, Kekuasaan dan Negara Pemikiran Politik Ibnu Khaldun, (Jakarta: PT. Gramedia, 1992), hal. XV.

10 Fuad Baali dan Ali Wardi, Ibn Khaldun dan Pola Pemikiran Islam, terj. Mansuruddin, Jakarta: Pustaka Firdaus, 1989), hal. 9. 
bahkan tidak optimal dalam perkembangan berikutnya. ${ }^{2}$ Agama dalam konteks negara dilihat sebagai budaya yang memiliki fungsi profetik. Kebijakan pemerintahan dikelola dengan tujuan-tujuan transenden. Termasuk pada urusan mempertahankan loyalitas rakyat. ${ }^{3}$

Memahami perkara negara dalam perspektif politik Islam bukaniah sesuatu yang mudah dalam pandangan Nurcholish Madjid. Ada dua alasan yang dikemukakan yaitu pertama, Islam telah berlangsung selama 14 abad. Maka tidak dapat dikatakan jika Islam berhenti dan mengalami stagnasi selama kurun waktu tersebut. Kedua, bahan-bahan kesejarahan telah muncul dalam waraa dan bentuk yang beranekaragam. Setiap gejala sejarah yang penting maupun sebuah peristiwa maka akan memunculkan perbendaharaan teoritis yang berbeda dengan apa yang ada sebelumnya. Walaupun susah dalam memahami hal tersebut, selalu saja menarik dalam melihat hubungan antara agama dan perilaku politik. ${ }^{5}$ Jika Amerika Serikat dianggap sebagai salah satu negara yang mempraktikkan demokrasi, maka selalu saja hasil penelitian menunjukkan tetap adanya keterkaitan antara agama dengan politik. Hanya saja dalam skala privat dan tidak dalam bentuk publik. ${ }^{6}$ Oleh karena itu, tidak dapat dilakukan penyeragaman akan praktik dan nilai yang dianut dalam melembagakan urusan negara.

Setiap komunitas atau masyarakat tentu mempunyai nilai sendiri yang berhubungan pelaksanaan tata pemerintahan. Bahkan jika sekalipun itu dinamai demokrasi, maka selalu saja ada dua hal yang berbeda seiring dengan perbedaan tempat. Pertama bahwa demokrasi tidak menjadi satu-satunya prinsip yang digunakan dalam menjelaskan hubungan antar warga Negara. Kedua, ada saja perbedaan menyikapi kondisi antara tempat yang satu dengan yang lainnya.

${ }^{2}$ Carl J. Friedrich, Man and His Govemment, An Empirical Theory of Politics, (New York: Mc Graw Hill Book Coy, Inc., 1963).

${ }^{3}$ Robert N. Bellah, The Broken Covenant: American Civil Religion in a Time of Trial, New York: Seabury, 1975).

"Nurcholish Madjid, "Kata Sambutan" dalam Munawir Syadzali, Islam dan Tata Negara: Ajaran, Sejarah dan Pemikiran, Jakarta: UI-Press, 1990), hal. vi-vii.

${ }^{5}$ Kenneth D. Wald, Religion and Politics in the United States, Washington DC: Congressional Quarterly Press, 1992), hal. 7-38.

${ }^{6}$ David C. Leege, The Parish as Community, Notre Dame Study of Catbolic Parish Life, Report 10, Notre Dame, IN: University of Notre Dame, 1987). 
Berkenaan dengan pandangan bahwa politik itu kotor, maka Ibnu Khaldun justru melihat bahwa manusia dengan segala aspeknya tidak pernah sempurna. Selalu saja ada kekurangan yang melingkupi aktivitas manusia. Bahkan manusia itu sendiri tidak sempurna. Kesalahan-kesalahan yang mencul semata-mata adalah dikarenakan penggunaan kekuasaan untuk mencari keuntungan dan kesenangan pribadi. Untuk itu politik perlu digunakan untuk mencapai kemaslahatan bersama. Bukannya justru ditinggalkan dan kemudian tidak mengambil manfaat dari sistem politik yang ada.

Jika Islam dipandang sebagai sebuah sistem yang sempurna, maka tentunya tidak terlepas di dalam ajarannya bagaimana pengaturan akan prinsipprinsip yang berhubungan dengan etika pemerintahan. Termasuk di dalamnya memberikan pedoman tata hubungan bermasyarakat, berbangsa dan negara. Walaupun tidak ada perintah untuk menjalankan Islam sebagai sebuah negara tetapi pada saat yang sama juga tidak ada sama sckali larangan. Bahkan justru perintah untuk menjadikan Islam sebagai pegangan secara sempurna jelas termaktub dalam al-Quran. Adanya pemisahan faham bahwa agama dan negara adalah dua entitas yang terpisah, tidak terlepas dari pengalaman Eropa pada abad ke 14 dimara kekuasaan berada dalam posisi raja-raja saja. Sementara gereja tidak turut serta didalamnya. " Pada fase selanjutnya, cikal bakal negara bangsa yang ada di Eropa dengan bentuk seperti ini kemudian menyebar ke seluruh dunia. ${ }^{12}$ Maka, pandangan yang memisahkan antara negara dan agama diterima tanpa melihat adanya aspek historisitas tersebut. Oleh karena itu, penelitian ini akan menguraikan bagaimana hubungan agama dan negara dengan menggunakan perspektif politik Islam dengan mengambil kajian Malaysia.

\section{B. Islam dan Negara dalam Perdebatan}

Ada perdebatan tentang konteks Islam dan negara sampai saat ini. Terbagi dalam dikotomi antara yang melihat Islam yang bersua dengan agama. Scbaliknya, ada kelompok yang melihat agama tidak beriringan bersama negara.

1 Azyumardi Azra, "Kata Pengantar", dalam Bernard, Babasa Politik Islam, penerj. Ihsan Ali Fauzan, (Jakarta: Gramedia, 1994), hal. 3.

${ }^{12}$ Muhsin Mahdi, Ibn Khaldun's Pbilosopby of History, A Study in the Pbilosopby Foundation of the Science Culture, (Chicago: University Press, 1971), hal. 168. 
Walaupun demikian, posisi penelitian ini berada dalam wujud bahwa negara Islam merupakan satu pilihan model kenegaraan. Dalam praktiknya ada juga para politisi yang memilih tipikal ini. Sehingga tidak dapat dinafikan begitu saja. Walaupun secara wacana, ada juga pendapat yang menyanggah bahwa sesungguhnya negara Islam itu tidak pernah wujud. Salah satu penolakan datang dari Musdah Mulia yang menganggap bahwa kenyataan historis menunjukkan adanya kekuatan politik dari semangat beragama dalam Islam. Di saat wafatnya Rasulullah bukanlah wacana teologi atau hal lain yang menjadi perdebatan. Justru dalam detik-detik awal segmentasi berada dalam siapa pengganti Rasulullah. Ini dipandang Musdah Mulia sebagai islam semata-mata adalah kekuatan politik tetapi bukan negara. Walaupun istilah nilai demokrasi dan hak asasi manusia muncul jauh di belakang hari, tetapi Islam telah telah menjalankan dua hal ini tanpa menyebutnya dengan dua istilah tersebut. ${ }^{13}$

Justru semangat politik pulalah juga yang kemudian menjadi perpecahan, pertentangan bahkan sampai pada titik pembunuhan. Beberapa rentetan pembunuhan setelah Usman bin Affan diantaranya dipicu oleh kepentingan politik. ${ }^{14}$ Para pakar yang menolak pandangan adanya negara Islam kemudian mengajukan pandangan untuk mundukung argumentasi itu dengan menunjukkan bahwa rumusan negara Islam belum satu konsep. Jika tidak satu berarti di saat muncul perdebatan, ini bisa dipandang sebagai bukan sesuatu yang mutlak. Sekalipun tahapan Khulafa' al-Rasyidun dipandang sebagai masamasa ideal, namun setelahnya dalam masa Bani Ummayyah dan Bani Abbasiyah ada tahapan yang berbeda secara normatif. Tidak ada lagi ciri Islam yang bisa disebut sebagai negara yang ideal. ${ }^{15}$

Salah satu pandangan yang mendukung bahwa negara Islam itu wujud secara teori dan praktik adalah Badawi. Ketika terjadinya perjanjian bai'at (sumpah setia) yang diberikan oleh masyarakat Madinah, maka saat itulah merupakan titik tolak terbentuknya negara Islam. Mandat politik yang dimiliki tidak saja berupa wahyu Allah tetapi adanya pengakuan masyarakat Yastrib saat

${ }^{13}$ Musdah Mulia, Negara Islam: Pemikiran Politik Husain Haikal, (akarta: Paramadina, 2001), hal. 5-6.

${ }^{14}$ Philip K. Hitti, History of The Arab, (London: Macmillan, 1990), hal. 193.

${ }^{15}$ John L. Esposito, Islam dan Politik, (Jakarta: Bulan Bintang, 1990), hal. 370. 
itu sehingga menjadikan terbentuknya sebuah sistem yang disepakati oleh masyarakat dalam lingkungan Madinah. ${ }^{16}$ Fathi Osman merupakan ulama yang juga berada dalam garis ini. Dalam pandangannya, Islam merupakan kehidupan spiritual dimana agama ini menyediakan sistem yang komprehensif termasuk dalam urusan politik." Islam dipandang tidak saja sebagai agama semata-mata tetapi melebihi institusi keagamaan. Beberapa istilah yang muncul antara lain adalah agama dan negara ${ }^{18}$, juga ada istilah peradaban yang sempurna ${ }^{19}$. Antara yang mendukung juga bahwa Islam merupakan agama dan negara secara bersama.an adalah al-Mawardi. Islam dipandang tidak semata-mata sebagai dimensi ritual. Tetapi lebih dari itu, menyandang juga dimensi politik. Doktrin al-Mawardi sampai pada bahwa tidak perlu ada pemisahan antara politik dengan Islam, dua dimensi antara Islam dan negara merupakan sisi yang saling melengkapi sehingga tidak dapat dipisahkan begitu saja. Justru harus dipandang dalam hubungan yang fungsional, agama dan politik tidaklah kontradiktif. Pada satu sisi politik akan melindungi agama dan di sisi berikutnya politik akan dikawal oleh agama. ${ }^{20}$

Secara historis, sesungguhnya pemisahan antara antara negara dan agama berdasarkan pengalaman adanya pertentangan antara kerajaan dengan Paus yang memerlukan waktu yang lama dengan kejadian yang sangat kompleks. Ada dua kejadian yang dapat dirujuk yaitu penobatan Gregory VII dan Henry IV. Begitu pula konflik antara Bonafice VIIl dan Philip yang kemudian menjadi contoh dengan dua kesimpulan yang berbeda. Pertama, bisa saja ditemukan hubungan antara gereja dengan agama dengan harmonis jika ada komunikasi tanpa subordinal dengan kemerdekaan masing-masing. Pendapat yang kedua menyatakan bahwa perlu otoritas tunggal yang membawahi dua organisasi. Pada perkembangan berikut justru adanya kesulitan intuk menetukan batas pembeda antara masalah agama dan masalah keduniawian.

${ }^{16}$ Tsarwat Badawi, al-Nushum al-Siyasah, Juz I, (Lebanon: Dar al-Fikr, 1998), hal. 37.

17 Fathi Osman, "Parameters of the Islamic State", Arabia. The Islamic World Review, No. 17. Januari 1983), hal. 10.

${ }^{18}$ Taha Abd al-Bagi Surur, Dawla al-Quran, (Kairo: Dar al-Nadha Misr, 1972), hal 80.

${ }^{19}$ HAL. A. R. Gibb (peny.) Whither Islam? A Survey of Modem Movements in the Moslem World, (London: Victor Gollancz Ltd., 1932), hal. 12.

${ }^{20}$ Abu al-Hasan Ali al-Mawardi, al-Ahkam al-Sulthaniyyah, (Lebanon: Dar al-Fikr, tt), hal. 5. 
Akhirnya, tahun 494 kemudian Paus Gelasius I yang berhasil merumuskan doktrin yang dikenal "dua pedang".

Pandangan Gelasius yang disebut sebagai pandangan tradisional dalam hubungan gereja-negara, ada tiga hal yang kemudian bisa diuraikan dari pandangan tersebut. Pertama, ada penolakan secara tegas kewujudan Negara teokrasi. Dimana pada saat yang sama pendeta akan menjalankan dua kekuasaan, politik dan spiritual. Adanya pembedaan antara regnum dan sacerdotium serta masing-masing dengan yurisdiksi yang berbeda. Hubungan yang terbangun antara keduanya bersifat independen. Meskipun mempunyai hubungan, tetapi otoritas yang diàapatkan berbeda walaupun asalnya sama yaitu dari Tuhan. Dalam wilayah kekuasaan masing-masing, mempunyai kedudukan yang tertinggi. Terakhir, tidak ada garis demarkasi yang jelas dan final. Selalu saja dalam hubungan tertentu ada kekuasaan yang satu terhadap yang lainnya. Walaupun Gelasius tidak menyatakan dimana kekuasaan terakhir yang akan menjadi eksekutor dalam masalah khusus, tetapi ada penekanan terhadap tanggung jawab pendeta yang lebih besar. Ini dapat diartikan bahwa keputusan tertinggi diberikan kepada sacerdotium.

Pendapat yang lain menjelaskan adanya perbedaan prinsip antara teologi politik dalam Islam dengan keyakinan yang lain. Jika dalam pemahaman teologi Kristen bahwa ada pemisahan antara negara dan agama secara radikal, maka berbeda dengan pemahaman Islam. ${ }^{22}$ Kebenaran sejati datangnya dari wahyu Allah. Dengan berdasar pada firman Allah ini, maka ketika diperhadapkan dengan kebenaran politik, maka Islam yang akan menuntun subjektivitas dan objektivitas dalam bersikap. Islam dijadikan sebagai panduan dalam pengambilan keputusan. Sehingga sumber dan asal untuk melakukan justifikasi merupakan mandat dari Allah sebagai khalifah di muka bumi. ${ }^{23}$

Pandangan ini didasari bahwa sesungguhnya syariat Islam akan senantiasa memenuhi kebutuhan masyarakat penganutnya. Selalu saja ada jalan

${ }^{21}$ R. W. Carcyle dan A. J., A History of Medieval Political Theory in The W'est, Vol. 5 , (London: Blackwood, 1928), hal. 190.

22 Asta Olesen, Islam and Politics in Afgijanistan, (Curzon Press: St. John's Studios, Church Roadl Richmond, Surrey, 1996), hal. 1.

${ }^{23}$ Yusuf Qaedhawi, Min Figh al-Daulab fi al-Islam, (Kairo: Dar al-Syuruq, 1997), hal. 30. 
keluar yang paling adil dalam memecahkan masalah yang akan memberikan dampak maslahat. Ini dapat saja terjadi karena adanya dua hal penunjang yaitu kesempatan dan faktor-faktor pokoknya yaitu asas utama dengan berlandaskan kepada pemahaman rasional. Demikian pula senantiasa terkandung di dalamnya sifat elastis dan sesuai dengan fitrah kemanusiaan. Selanjutnya syariat juga bertujuan untuk menjaga keseimbangan antara hak dan kewajiban, rohani dan jasmani, dunia dan akhirat. Secara praktis senantiasa akan menegakkan keadilan dalam kehidupan, pada saat yang sama juga mengupayakan kemaslahatan dan kcbaikan. Pada akhirnya akan menolak kerusakan dan kejahatan dalam batas maksimal. Pada dasarnya syariat sudah ditetapkan Allah dengan melibatkan sifat luwes. Ini untuk memberikan kesempatan ketika muncul masalah baru yang tibul dalam kehidupan manusia, maka dapat saja diselesaikan dengan menggunakan dasar syariat tersebut. ${ }^{24}$

Perdebatan diatas muncul jika kemudian melihat bentuk-bentuk pemerintahan yang berlangsung sejak zaman kenabian. Dimana pembentukan negara Islam memang tidak wujud dalam kata daulah. Melainkan fungsi-fungsi kenegaraan justru sudah berlangsung sejak hijrah Nabi Muhammad ke Medinah. Tetapi argumentasi yang menyatakan bahwa Islam tidak memberikan perintah akan pembentukan negara dapat dipahami. Hanya saja justru ada perintah yang memberikan arahan untuk menyempurnakan seluruh dimensi kehidupan secara sempurna. Jika ini dilihat sebagai perintah, maka di dalamnya akan termasuk pula perintah untuk menjalankan fungsi-fungsi tata kelola pemerintahan dengan spirit keislaman. Maka, kesimpulan yang dapat diajukan bahwa Islam memandang perlu penegakan hukum untuk memberikan keluasan bagi terbentuknya masyarakat yang menerpakan nilai keagamaan secara sempurna.

\section{Tinjauan Penelitian Terdahulu}

Penelitian berkenaan dengan agama dan Negara telah dijalankan beberapa pakar antara lain Bahtiar Effendy. Penelitian ini dilakukan pada awal tahun 1990-an sampai 1992, sehingga hanya memotret perjalanan dinamika

24 Muhammad Daud Ali, Hukum Islam di Indonesia, cet. III, Oakarta: PT. Raja Grafindo Persada, 2002), hal. 1. 
hubungan agama dan negara dalam konteks orde baru. Penelitian Bahtiar menunjukkan bahwa untuk kajian Islam dan negara di Indonesia, pemerintah Orde Baru menggunakan Islam sebagai wacana dalam bentuk formal. Sementara jika berada dalam konteks implementasi syariah, itu tidak menjadi agenda utama pemerintah. Demikian pula dengan masyarakat yang tidak lagi memandang adanya kepentingan menggunakan agama sebagai ideologi untuk bernegara melalui pilihan representansi di partai politik. Partai Fersatuan Pembangunan (PPP) yang menggunakan Islam sebagai dasar perjuangan sepanjang Orde Baru justru tidak mendapatkan mayoritas dukungan. Dalam beberapa provinsi bahkan menempati urutan yang terakhir dari uga partai politik yang ada saat itu. ${ }^{25}$

Penelitian berikutnya dilaksanakan Syafii Maarif dengan judul "Islam as the Basis of State: A Study of the Islamic Political Ideas as Reflected in the Constituent Assembly Debates in Indonesia". Syafii Maarif meneliti bagaimana diskusi dan argumentasi tentang ide-ide yang didasarkan pada Islam. Partai politik yang memiliki kursi di Majelis Perwakilan Rakyat terkadang menggunakan Islam sebagai pendukung argumentasi. Penelitian ini menunjukkan Islam sebatas digunakan untuk memperkuat wacana, sementara dalam kelembagaan negara, Islam tidak digunakan sebagai aturan formal. ${ }^{26}$ Adapun penelitian Mehden sebatas melihat nasionalisme dan Islam diIndonesia. Penelitian ini tidak secara tegas mengkaji hubungan dengan negara. Sematamata meneliti kebangkitan nasionalisme yang terjadi dalam kehidupan warga negara. $^{27}$

Penelitian juga dilakukan oleh Lukman Thaib dengan judul "Islamic Political Representation in Malaysia". Lukman menggambarkan bagaimana model syura yang menjadi pilar politik dalam Islam berjalan dengan kondisi Malaysia. Secara khusus Lukman juga menguraikan representasi pada Negeri

25 tahtiar Effendy, Islam and The State in Indonesia, (Singapura: ISEAS, 2003), hal. 222-223.

${ }^{26}$ Ahmad Syafii Maarif, Islam as the Basis of State: A Study of the Islamic Political Idear as Reflected in the Constituent Assembly Debates in Indonesia, Disertasi, (Chicago: University of Chicago, 1983).

${ }^{27}$ Fred R. von der Mehden, Islam and the Rise of nationalism in Indonesia, disertasi, (Berkeley: University of California Berkeley, 1957). 
Kelantan. Pilihan ini didasarkan bahwa saat penelitian dilakukan satu-satunya Negeri yang dikuasai oleh oposisi hanya Kelantan. Partai Islam Semalaysia (PAS) yang memegang mayoritas kursi Dewan Negeri menyuarakan pentingnya untuk meluluskan hukum hudud dalam Enakmen Syariah Negeri. Tetapi usulan ini mendapat penolakan dari Pemerintah Federal. Dengan kewenangan yang dimiliki Dewan Negeri sebagai pembuat undang-undang sebagaimana mandat yang diberikan Perlembagaan Malaysia. Padahal Enakmen Negeri yang diusulkan Majelis Kerajaan Negeri telah mendapat persetujuan melalui diskusi dengan rakyat Kelantan serta sudah disetujui oleh Dewan Negeri. ${ }^{28}$ Dalam pandangan Lukman Thaib ini merupakan praktik yang tidak berjalan sebagaimana harapan. Dimana penetapan Enakmen Negeri Kelantan sematamata tertunda hanya saja karena persetujuan Pemerintah Federal dengan pertimbangan politis.

Sementara itu penelitian yang dilaksanakan Susilawetty sebatas melihat hukum waris di Malaysia. ${ }^{29}$ Tetapi tidak mengkaji sisi politik. Adapun Wan Kamal Wan Napi mengkaji politik Islam tetapi tinjauan ini dilaksanakan dalam melihat analisis framing dalam surat kabar Malaysia. Kajian Wan Kamal Wan Napi tidak mengkaji ide-ide politik tetapi membahas bagaimana media melaksanakan agenda setting sehubungan dengan politik yang ada. ${ }^{30}$ Penelitian terkini dilakukan Azlan R. Yahaya. Penelitian ini khusus meneliti pidato-pidato Tun Abdullah Ahmad Badawi ketika menjabat sebagai perdana mentri Malaysia. Penelitian ini juga tidak secara khusus mengkaji bagaimana politik dalam pidato tersebut. Tetapi pemilihan teks pidato ditinjau dari segi teori-teori komunikasi massa. Tetapi tidak dilihat dalam konteks politik dan agama di Malaysia. ${ }^{31}$ Sehubungan dengan fenomena merebaknya musim semi di kawasan Arab yang

28 Lukman Thaib, Istamic Political Representation in Malaysia, (Kuala Lumpur: University of Malaya Press, 2005), hal. 202-203.

29 Susilawetty, "Implementasi Ketentuan Hukum Waris Islam Indonesia dan Malaysia", dalam Jumal Reformasi Hukum, Vol. XI, No. 2, (Desember, 2008), hal. 130- 149.

${ }^{30}$ Wan Kamal Wan Napi, The Islamization Of Politics In Malaysia: How Religious Political Opportumities and Tbreats Influence Religious Framing and Counterframing, disertasi, (Carbondaic: Southem Illinois University, Desember 2007).

${ }^{31}$ Azlan R. Yahaya, Islom Hadhari: An Ideological Discourse Analysis of Selected Speeches by UMNO President and Malaysia Prime Minister Abdullah Abmad Badawi, disertasi, (Amerika Serikat: Scripps College of Communication of Ohio Univetsity, 2012). 
dikenal dengan istilah "Arab Spring" salah satu tim peneliti yang mengkaji adalah Bradley J. Cook dan Michael Stathis. Dalam penelitian ini melihat hubungan antara demokrasi dan Islam. Cook dan Stathis justru memfokuskan pada analisis tentang kesamaan antara konsep demokrasi dan Islam. Sehingga sampai pada kesimpulan bahwa sesungguhnya politik dalam hal ini terminologi demokrasi dan agama sesungguhnya senantiasa berjalan seiring. Sehingga setiap agama dan negara perlu menemukan relasi yang cocok untuk diimplelemtasikan dalam konteks geopolitik masing-masing. Tanpa perlu kemudian terpengaruh oleh dinamika perkembangan negara lain. ${ }^{32}$

Kajian penelitian terdahulu di atas menggambarkan bahwa penelitian tentang negara, Islam dan demokrasi telah dijalankan. Hanya saja kajian-kajian tersebut sebatas melihat nasionalisme di negara dengan mayoritas penduduk muslim seperti Indonesia. Begitu pula ada kajian tentang politik tetapi membatasi pada isu-isu politik dalam media massa. Sementara kajian yang melihat relevansi demokrasi dan Islam pada wilayah Arab juga telah dilakukan. Namun penelitian tersebut merupakan pembahasan "Arab Spring" sebatas mengkaji bagaimana para pelaku unjuk rasa di negara-negara tersebut. Dengan demikian, ada distinction untuk menjalankan penelitian ini. Setelah pemaparan penelitian yang bethubungan dengan Malaysia, demokrasi dan Islam. Oleh karena itu, penelitian ini menemukan relevansi dimana para peneliti sebelumnya tidak khusus meneliti kajian akan agama dan negara terutama di Malaysia. Penelitian ini bermaksud mengkaji bagaimana menempatkan Islam dalam pemerintahan Malaysia, salah satu faktor yang dikaji adalah dinamika posisi Islam yang berkembang bersama dengan politik.

\section{Malaysia dan Dasar Negara Islam}

Angka statistik menunjukkan bahwa luas Malaysia terbentang dengan wilayah mencapai $329.847 \mathrm{~km} 2$. Adapun etnis Melayu mencapai $62 \%$ dengan komponen lainnya $24 \%$ China, $8 \%$ India dan sisanya terdiri atas suku terasing

32 Bradley J. Cook dan Michael Stathis, "Democracy and Islam: Promises and Perils for the Arab Spring Protests", dalam Joumal of Global Responsibility, Vol. 3, No. 2, 2012, hal. 175 186. 
dan minoritas lainnya. ${ }^{33}$ Dengan berdasarkan pada ketuanan Melayu, Islam menjadi nafas dan ruh dalam pelaksanaan aktivitas rakyat Malaysia terutama yang berctnis Melayu. Dengan dukungan perlembagaan Malaysia, kaum Melayu kemudian menjalankan aktivitas dengan didasari prinsip-prinsip Islam. Termasuk dalam pelaksanaan pengembangan sumber daya manusia. Penelitian Junaidah menunjukkan bahwa nilai dan sikap yang diadopsi dari nilai-nilai Islamı. Istilah bumiputra juga digunakan secara luas untuk memberikan keistimewaan bagi rakyat Malaysia dari kalangan Melayu. Termasuk di dalamnya penyediaan sarana ibadah seperti surau dan masjid di kalangan perkantoran. ${ }^{34}$ Ini dimaksudkan untuk mendukung kemudahan melaksanakan ibadah bagi umat Islam.

Malaysia merupakan salah satu negara yang multietnik tetapi dengan tegas menyatakan bahwa Islam menjadi dasar penyelenggaraan tata pemerintahan. Tidak hanya dalam pemerintahan tetapi juga dalam perekonian secara umum. Di awal tahun 1980 mulai memperkenalkan sistem perbankan syariah. ${ }^{35}$ Di samping tetap memberikan keluasan bagi perbankan dengan system konvensional. Bahkan dengan tegas kemudian menyelenggarakan dua sistem perbankan dalam satu negara. Dalam penelitian Benson membuktikan bahwa sistem perbankan syariah dapat bersaing dengan perbankan konvensional. ${ }^{36}$ Dalam beberapa hal justru perbankan dengan prinsip-prinsip syariah lebih dapat memenuhi tuntutan pasar serta memperoleh profit yang tinggi.

Artikel 3 (1) memberikan penegasan bahwa Islam merupakan agama resmi pemerintahan. Dengan demikian, ini menjadi bukti ketatanegaraan yang

${ }^{33}$ Malaysian Statistics Department, Malaysian Population Survey, (Kuala Lumpur: Malaysian Government, 2006

${ }^{34}$ Junaidah Hasyim, "Islamic Revival in Human Resources Management Practices among Selected Islamic Organisations in Malaysia", dalam Jourmal of Islamic and Middle Easterm Finance and Management, Vol. 2, No. 3, (2009), hal. 251-267.

${ }_{35}$ Obiyathulla Ismath Bacha, "The Islamic Interbank Money Market and a Dual Banking System; the Malaysian Experience", dalam Intemational Journal of Islamic and Middle Eastem Finance and Management, Vol. 1, Iss: 3, 2008, hal. $210-226$.

${ }^{36}$ K.L. Benson, T.J. Brailsford, dan J.E. Humphrey, "Do socially responsible fund managers

really invest differently?", dalam Joumal of Business Ethics, Vol. 65, (2006), hal. 337-57. 
menunjukkan bahwa Islam sebagai dasar bernegara. Untuk memahami penjelasan keadaan tersebut, Wan Zahidi menggunakan empat pendekatan. ${ }^{37}$ Pertama, pembentukan asas teoritis. Penjelasan tambahan dikeluarkan oleh Jabatan Kemajuan Islam Malaysia bahwa Malaysia merupakan bentuk negara Islam. Ini berarti bahwa kekuatan dan pertahanan dikuasai sepenuhnya orang Islam berserta dengan perangkat pemerintahan. Oleh karena itu, menjadi kewajiban setiap individu muslim Malaysia untuk mempertahankan keberadaan negara. Kedua, qias. Nakhaie memandang bahwa keberadaan Malaysia tidaklah terlepas dari kondisi global dimana kepemimpinan umat Islam mulai menurun. Sehingga tidak dapat disamakan lagi dengan kondisi yang terjadi pada saat Khulafa al-Rasyidun atau Abbasiyah dan Umayyah. Dengan demikian, dengan segala prasyarat yang ada serta kondisi lingkungan, maka dapat saja Malaysia disebut sebagai negara Islam dengan bentuknya yang ada. ${ }^{38}$ Ketiga, ciri dan kriteria. Jika menggunakan pendekatan ini, maka apa yang ada dalam konsep negara Islam seperti syura sesungguhnya tidak berbeda dengan ciri dan kriteria yang sudah ada sejak zaman pemerintahan Islam. Belum lagi pada hal kepemimpinan, kemaslahatan, dan penguasaan tanah air. Terakhir, akal dan logis. Dalam kategorisasi negara, hanya ada negara Islam dan negara kafir. Sehingga jika memasukkan Malaysia kedalam kategori negara kafir, maka mungkin saja ini tidak dapat dilakukan. Karena tidak ada kategori yang ketiga. Oleh karenanya, dengan keadaan yang selemah apapun, tetap saja Malaysia dimasukkan dalam kategori negara Islam.

Bagi yang mengemukakan ide tersebut di atas sejalan dengan pernyataan Mohammed Natsir bahwa sesungguhnya secara literal dan praktis Islam ticak perlu mengajarkan bagaimana hal-hal yang teknis. Seperti kemampuan menjalankan pesawat dan memasang listrik. Sebab Islam memang adalah pandangan hidup yang memandu manusia tidak saja dalam zaman tertentu

${ }^{37}$ Wan Zahidi Wan Teh, Malaysia Daulah Islamiah, Makalah disampaikan perjumpaan YAB Perdana Menteri bersama Pegawai-pegawai Agama Islam seluruh Malaysia, 28 - 29 Agustus, Putrajaya: JAKIM, 2000, hal. 4

38 Ahmad Nakhaie, Jibad Guru Agama dalam Pembangunan Bangsa Melayu dan Pembentukan Negara Islam Maju, makalah disampaikan dalam Kuruss Khas Perdana (Pendidikan Islam), 22 Mei 2001, Kuala Lumpur, hal. 8- 21. 
tetapi menjadi kekal sepanjang masa. Kemampuan teknis seperti yang sudah disebutkan itu, bisa saja berubaha mengikuti perkembangan pemikiran manusia dan kemajuan teknologi. Sehingga tidak akan berterima jika agama kemudian ditinggalkan hanya karena ketidakmampuan merespon perkembangan teknologi yang ada. ${ }^{39}$ Penolakan akan pandangan ini diajukan oleh beberapa kelompok lain, diantaranya Partai Islam Semalaysia (PAS). Penjelasan bahwa Malaysia sebagai negara Islam tidak diterima. Ada beberapa argumentasi yang dikemukakan saat menyampaikan dokumen yang berjudul Negara Islam pada 12 November 2003 yang bertepatan dengan 17 Ramadhan $1424 \mathrm{H}$.

Abdul Hadi Awang, Presiden PAS mengemukakan bahwa diperlukan amandemen perlembagaan Malaysia jika kemudian memang akan memproklamirkan sebagai negara Islam. Jika hanya mengemukakan sebagai tanah air dan negara Islam, maka dalam konteks tanah air, maka ciri ini sudah sempurna dan serasi. Hanya saja sebagai negara Islam, syariah tidak dilaksanakan. Dalam penjelasan PAS bahwa hukum syarak dan kekuatan untuk menjalankan praktik dan fungsi bagi berjalannya hukum-hukum Islam tidak diatur secara hukum ketatanegaraan. Akidah Islam sebagai landasan pokok bagi erwujudnya hukum Islam tidak pernah disetujui oleh pemerintah federal. PAS mengemukakan bahwa saat memerintah Terengganu 1999-2004 ada persetujuan pemerintah Negeri Terengganu untuk Undang-undang Jenayah Syariah Negeri. Tetapi ini tidak dapat terlaksana karena persetujuan Pemerintah Persekutuan tidak didapatkan. Demikian pula Dewan Undangan Negeri Kelantan juga menyetujui Kod Jenayah Syariah Kelantan. Pemerintah Federal juga menolak pelaksanaanya. Walaupun Perlembagaan Persekutuan memberikan keluasan kepada setiap negeri untuk menyusun enakmen, tetapi tetap saja dengan kewenangan yang ada pada Pemerintah Persekutuan selalu menolak pelaksanaanya.

Perdebatan di atas menunjukkan bahwa dasar negara Islam di Malaysia masih saja terdapat dua kelompok besar, antara yang mendukung dan monolak. Hanya saja perdebatan yang ada dilakukan oleh kelompok-kelompok politik.

${ }^{39}$ Mohamed Natsir, "Agama dan Negara", dalam M. Isa Anshary, Falsafab Perjuangan Islam, (Medan: Penerbit Saiful, 1951), hal. 129. 
Sesungguhnya jika melihat perdebatan dua kelompok ini, maka berada dalam tataran nilai dan sistem yang dianut. Islam sebagai prinsip sudah disetujui secara bersama. Hanya saja dalam pelaksanaan secara praktik yang tidak mendapatkan persetujuan kedua belah pihak. UMNO lebih memandang bahwa negara Islam sebatas pada pelaksanaan prinsip yang utama. Sementara PAS lebih menekankan adanya kebutuhan untuk menjalankan syariat Islam secara implementatif dengan mendapatkan dukungan peraturan perundang-undangan. Sekaligus dilihat adanya ketidakselarasan, dimana enakmen syariah hanya berlaku di negeri-negeri. Sehingga diperlukan pemberlakukan syariah juga dalam tingkatan persekutuan.

\section{E. Mengenal Tata Pemerintahan Malaysia}

Islam wujud sebagai pengakuan kelembagaan dalam negara. Ini termaktub dalam sistem ketatanegaraan Artikel 3 (1) yang menyebutkan "Isiam ialah agama bagi Persekutuan, tetapi agama-agama lain boleh diamalkan dengan aman dan damai dimana-mana bahagian persekutuan". " Islam berfungsi sebagai rujukan tata perilaku atas segala aktivitas yang dijalankan. Demikian pula disebutkan bahwa Melayu adalah beragama Islam. ${ }^{41}$ kebebasan beragama hanya berlaku untuk warga negara yang bukan Islam. Sementara bagi warga dengan status etnis yang dalam bahasa Melayu disebut bangsa wajib beragama Islam. Selanjutnya Sultan dijadikan sebagai kepala negara dengan kekuasaan utama menjaga tradisi Islam. Sehingga pelaksanaan undang-undang untuk urusan Islam telah diletakkan dalam perlembagaan. ${ }^{42}$ Ini menunjukkan secara hokum formal bahwa Islam merijadi agama utama di Malaysia.

Kekuasaan legislasi berada di tangan parlemen sekaligus juga sebagai kekuatan eksekutif. Sehingga dalam urusan legislasi tidak ada desentralisasi ke negeri-negeri yang ada. Sekaligus Sultan dan Yang Dipertua setiap negeri

\footnotetext{
${ }^{46}$ Federal Constitution, (Kuala Lumpur: International Jaw Book Service, 2002), hal. 20.

${ }^{41}$ Mohammad bin Arifin, Islam dalam Perlembagaan Persekutuan, dalam Ahmad Ibrahim, dkk., Perkembangan Undang-undang Perlembagaan Persekutuan, (Kuala Lumpur: Dewan Bahasa dan Pustaka, 1999), hal. 99.

42 Mahmood Zuhdi Abd. Majid, Bidang Kuasa Mabkumab Syariah di Malaysia, (Kuala Lumpur: Dewan Bahasa dan Pustaka, 1997), hal. 103.
} 
bertanggungjawab penuh dalam mengurus tradisi yang berakar dalam semangat keislaman. Perlembagaan Persekutuan yang menjadi undang-undang tertinggi memberikan mandat bahwa hal yang berkaitan dengan hal ihwal agama Islam diberikan kepada kewenangan negeri sebagaimana Jadual Kesembilan Senarai 2 Butir 1. Jika dibaca bersama dengan Perkara 4 (1) dan 75, maka undang-undang yang berada dalam cakupan setiap negeri yang disebut Enakmen masih dalam kondisi bersyarat yaitu tidak bertentangan dengan Undang-undang Persekutuan. Demikian pula halnya dengan Akta Mahkamah Syariah 1984 bahwa kekuasaan kehakiman untuk Mahkamah Syariah yaitu menyidangkan perkara dengan hukuman yang tidak melebihi tiga tahun penjara. Adapun denda tidak melebihi lima ribu ringgit. Untuk hukuman cambuk tidak lebih dari enam cambuk. Sementara jika digabung, tidak melebihi gabungan ketiga hukuman tersebut.

Pada tahun 1980-an diberlakukan pemisahan Undang-undang Jenayah Syariah menjadi Enakmen Kanun Jenayah Syariah yang tersendiri. Ada 14 Kanun Jenavah Syariah yang diberlakukan yaitu Kelantan (1985), Kedah (1998), Melal:a (1991), Sarawak (1991), Negeri Sembilan (1992), Perak (1992), Perlis (1991), Selangor (1995), Johor (1997), Wilayah Persekutuan (1997), Sabah (1995), Terengganu (1986), Pulau Pinang (1993) dan Pahang (1991). Sementara untuk kalangan pelajar dan mahasiswa juga diatur dalam Akta Universiti dan Kolej Universiti 1971 (AUKU) larangan bagi pelajar dan mahasiswa untuk berbuat tidak senonoh pada hal-hal yang bertentangan dengan ajaran Islam. Ini dilakukan untuk menjaga kepentingan universitas dan aktivitas di luar kampus menjadi satu hal yang diatur dalam undang-undang tersebut. Termasuk melarang pelajar dan mahasiswa untuk terlibat dalam kegiatan politik ataupun juga organisasi yang tidak mendapatkan pengakuan pihak pimpinan universitas.

Untuk pelaksanaan musyawarah dilaksanakan dalam dua tingkat yaitu pariemen dan dewan rakyat. Parlemen dipilih berdasarkan pemilihan umum mewakili kawasan tertentu. Sementara dewan rakyat yang disebut dengan senator diangkat atas usulan negeri-negeri. Wilayan kekuasaan dibagi ke dalam dua tingkatan yaitu tingkatan federal (persekutuan) dan negeri-negeri. Ada dua wilayah federal yaitu Putra Jaya dan Labuan. Sementara Kuala Lumpur dikelola sebuah walikota yang disebut Datuk Bandar. Diangkat langsung oleh Menteri 
Dalam Negeri. Adapun gubernur atau Mentri Besar dipilih melalui pemilihan umum yang berasal dari partai pemenang di tingkatan negeri tersebut. Setiap negeri punya kewenangan untuk menetapkan udang-undang yang berkenaan dengan urusan Islam. Undang-undang ini khusus berlaku dalam wilayah mereka. Selangor merupakan negeri pertama yang telah menetapkan undangundang Islam pada tahun 1952. Selanjutnya negeri-negeri lain juga melakukan hal yang sama. ${ }^{43}$ Tahun 1998 secara keseluruhan semua negeri sudah menetapkan enakmen syariah.

Pada praktiknya, madhzab yang dijalankan bersumber pada pandangan Syafi'i. madzhab yang lain walaupun diakui tetapi tidak menjadi rujukan resmi. Sehingga dalam keseharian hanya ada satu madzhab yang diajarkan dalam pendidikan formal. Di perguruan tinggi, seperti Fakultas Kajian Islam di Universitas Kebangsaan Malaysia madzhab lain diajarkan tetapi sebatas pengenalan dalam wacana saja. Secara de facto hanya madzhab Syafi'i yang digunakan. Sebagaimana dalam praktik di Mahkamah Syariah serta fatwa ulama. Rujukan-rujukan ulama dalam penetapan fatwa selalu mendasarkanpada pertimbangan dalam lingkup madzhab Syafi'i. ${ }^{44}$ Walaupun tidak disebutkan secara khusus dalam perundang-undangan. Pada persoalan akidah demikian pula, hanya ulama yang menjadikan madzhab Syafi'i saja yang digunakan sebagai rujukan. ${ }^{45}$ Ini menunjukkan bahwa madzhab yang digunakan baik dalam pendidikan, ibadah maupun peradilan hanya madzhab Syaifi'i.

Dalam urusan agama, maka sultan di masing-masing negeri pemimpin agama. Seperti zakat, secara kelembagaan dikelola oleh badan independen di masing-masing negeri. Seperti di Selangor didirikan lembaga Zakat Selangor dengan pimpinan seorang pengarah yang ditunjuk oleh Mentri Besar masingmasing negeri dengan hiraki pertanggungjawaban ke sultan atau Yang Dipertua

${ }^{43}$ M. B. Hokker, Islamic Law in South-East Asia, (Kuala Lumpur: Oxford University Press, 1984), hal. 144.

${ }^{44}$ Ibrahim Abu Bakar, Islamic Modemism in Malaya, The Life and The Though of Sayyid Syaykb al-Hadi 1867-1934, (Kuala Lumpur: University of Malaya Press, 1994), hal. 17-18.

45 Ahmad Hidayat Buang, Kebebasan Memberi Pandangan dalam Isu-isu Agama Isiam: Kajian terbadap Fatwa-fatwa Jabatan Mufti Negeri-negeri di Malaysia, Makalah dalam Seminar Pemikiran Islam Peringkat Kebangsaan I di Akademi Pengajian Islam, Universiri Malaya, 11 Januari 2003, hal. 11-12. 
Negeri. Pengelolaan zakat sepenuhnya menjadi wewenang negeri-negeri. Untuk khusus urusan agama Islam maka secara teknis dijalankan oleh majelis agama negeri. Ketua majelis agama bertanggung jawab langsung kepada sultan. Pada tingkatan federal tidak terdapat kementerian khusus yang mengurusi agama. Tanggung jawab agama berada di tangan Perdana Menteri dibantu Menteri di kantor Perdana Menteri. Pemisahan ini menujukkan adanya keinginan kuat untuk pengurusan agama semata-mata menjadi wewenang sultan dan kerajaan. Schingga tidak dilaksanakan oleh para politisi.

Termasuk yang menjadi kewenangan pemerintah federal adalah pengawasan terhadap ajaran sesat. $\mathrm{Di}$ saat pemerintah memandang bahwa keberadaan ajaran sesat akan mengganggu ketentraman maka digunakan Akta Kesclamatan Dalam Negeri (Internal Security Act, ISA) dan gugatan oleh Jaksa Agung Malaysia diajukan di Mahkamah Sivil. Ini dipandang sebagai hal yang akan menggangu ketentraman umum. Sementara bagi umat yang melaksanakan ajaran sesat maka diberlakukan Kanun Jenayah Syariah yang berlaku dalam enakmen setiap negeri. Maka, apa saja yang bertentangan dengan hukum syarak akan menjadi kewenangan Jenayah Syariah. Tidak saja dalam tingkatan negeri, tetapi terdapat pula Akta Kesalahan Jenayah Syariah Wilayah Persekutuan 1997 ( $\Lambda$ kta 559). Walaupun ada juga yang beranggapan, perlu diperluas dari tafsiran yang ada. Skop yang ada selama ini terialu sempit sehingga hanya menyentuh perkara-perkara yang berhubungan dengan hukuman hudud. ${ }^{46}$ Kebutuhan akan figh kontemporer perlu diakomodasi dalam enakmen dan juga jenayah siyasah.

Sernentara partai politik menganut sistem multi partai. Namun pada pemilihan umum 2008, terbagi atas dua kelompok besar. Partai besar yang berada dalam kelompok Barisan Nasional, selanjutnya kelompok lain yang mengusung identitas oposisi menamakan diri Pakatan Rakyat. Untuk pertama kali dalam sejarah Malaysia pemilihan umum itu tidak dimenangkan 2/3 oleh Barisan Nasional yang terdiri atas UMNO, MCA dan kelompok oposisi terdiri atas PKR, PAS dan DAP. Pelaksanaan kehakiman diselenggarakan oleh pengadilan yang independen. Baik kekuasaan eksekutif maupun legislatif tidak memiliki kewenangan dalam penyelenggaraan kehakiman. Sebagai lembaga yang

${ }^{46}$ Op. Cit, Mahmood Zuhdi Abd Majid, hal. 134-140. 
merdeka dari kekuasaan yang lain, maka pengangkatan hakim agung dilaksanakan secara internal. Sistem pengadilan memberikan kewenangan seluas-luasnya kepada Mahkamah Syariah untuk mengadili perkara syariah sebagaimana dalam enakmen masing-masing negeri.

\section{F. Karya Ketatanegaraan dan Pemerintahan di Alam Melayu}

Jika hari ini kita banyak merujuk kepada karya-katya dari Eropa dan Amerika Serikat mengenai politik, maka sesungguhnya didapatkan warisan kitab-kitab dari alam Melayu dan Nusantara yang khusus membahas ketatanegaraan dan pemerintahan. Ini membuktikan bahwa perhatian terhadap peradaban tertinggi berupa ilmu pengetahuan demikian pula tata kelola pemerintahan sudah ada. Sekaligus menandakan bahwa Islam selalu menjadi jiwa para pembesar istana sejak dulu. Sebagai contoh, kitab Tsamarat alMuhimmah karya yang dikhususkan untuk mengenang Yang Dipertuan Muda Ali (wafat 1857 M). Sekaligus dikhususkan kepada istana Lingga-Riau tetapi justru dijadikan rujukan juga oleh kerajaan-kerajaan lain yang serumpun. Zalila Syarif dan Jamilah Ahmad juga memberikan gambaran bagaimana kita Taj alSalatin bukan saja digunakan sebagai panduan kekuasaan politik di semenanjung Aceh. ${ }^{47}$ Tetapi sampai dibaca juga di daratan Melayu, begitu pula kerajaan Siam, di Thailand. Kedua kitab itu membuktikan bahwa pengaruh Islam terhadap pemerintahan di Malaysia sudah ada sejak dulu dan bukan muncul secara tibatiba di abad ini. Karya seperti Taj al-Salatin dan Bustan al-Salatin merupakan karya yang berasal dari peninggalan abad ke-17. Ini menunjukkan bahwa sejak awal ketika harmoni antara Islam dan Melayu berkembang termasuk mempengaruhi aspek ilmu pengetahuan.

Ada tiga kategori karya yang dihasilkan. Pertama, karya terjemahan. Sebagian besar pengarang terdiri atas ulama dan pembesar istana. Dengan penguasaan terhadap kitab-kitab berbahasa Arab kemudian menginspirasi untuk menerjemahkan ke dalam bahasa Melayu. Kegiatan penerjemahan dilakukan baik secara resmi merupakan kegiatan kerajaan maupun juga atas inisiatif

47 Zalila Syarif dan Jamilah Haji Ahmad, Kesusasteraan Melayu Tradisional, (Kuala Lumpur: Dewan Bahasa dan Pustaka, 1993), hal. 499. 
pengarang scndiri. Terjemahan berupa karya di pelbagai bidang, antara lain fiqh, tauhid dan juga tata negara. Antara karya yang dihasillkan adalah nasihat alMuluk karya Wa'iz al-Khasafi dan Nasihat al-Mulk karya Imam al-Ghazali. Buku kedua tersebut berjudul sama dengan buku sebelumnya tetapi dihasilkan dari pengarang berbeda dan kajian yang berbeda pula. Harun Jelani menjelaskan bahwa terjemahan keduanya sangat teliti, sehingga kesalahan dan kesilapan dalam penerjemahan sangat susah ditemukan. ${ }^{48}$ Penerjemahan buku kemudian berjalan secara simultan sesuai dengan kebutuhan kerajaan.

Kedua, karya salinan dan saduran. Di saat ada keputusan yang akan diambil oleh penguasa, maka mereka selalu bertanya kepada para ulama. Sebagai contoh di saat pelantikan raja perempuan yang sebelumnya belum pernah didapatkan dalam tradisi kerajaan. Untuk menjawab ini, maka ulama merujuk kcpada kitab yang sudah ada. Kemudian disadur dalam bahasa Melayu. Ini dilakukan karena melalui tulisan, maka dapat disampaikan secara teratur dan jelas. Demikian pula dapat ditelaah kapan dan dimana saja. Selanjutnya tidak terbatas di kalangan raja saja. Tetapi penyelenggaraaan pemerintahan dapat merujuk kepada karya ini tanpa dibatasi oleh kendala apapun. Tidak saja oleh kalangan kerajaan, tetapi masyarakat umum juga dapat menyimak informasi dan juga pandangan ulama. Hasil olahan ulama inilah yang kemudian disesuaikan dengan kondisi alam Melayu. Diantara karya yang terbit ini antara lain Risalah fi al-Sahabah, Kitab al-Imamah wa al-Siyasah, al-Ahkam al-Sulthaniyyah wa alWilayah al-Diniyyah.

Terakhir, karya yang terinspirasi dari peradaban Islam di wilayah lain. Pengaruh wilayah lain yang lebih dahulu menerima Islam kepada alam Melayu memberikan inspirasi untuk menulis buku yang sama. Karya seperti Qabusnama dan Akhlak al-Muhsini yang dihasilkan di Persia, memberikan pengaruh dalam nukilan dan karya pemikiran ulama di tanah Melayu. Salah satu pengarang besar yang ada yaitu Raja Ali Haji. Beliau penulis karya monumental Tsamarat alMubimmah dan Muqaddimah fi Intizam. Kedudukan Raja Ali Haji sebagai keturunan Raja Ahmad yang merupakan pembesar di kerajaan Johor-Riau

\footnotetext{
48 Jelani Harun, Pemikiran Adab Ketatanegaraan Kesultanan Meiayu, (Kuala Lumpur: Dewan Bahasa dan P'ustaka, 2003), hal. 38.
} 
kemudian memberikan pengaruh penting untuk memberikan pandanganpandangan dalam tata kelola pemerintahan. Apalagi beliau beberapa kali inenjadi utusan untuk perundingan kerajaan Johor-Riau dengan Gubernur Jenderal Hindia Belanda di Betawi. Sehingga sebelum menuju ke perundingan, beliau terlebih dahulu menuangkan gagasan dan pokok pikiran ke dalam tulisan. Karya inilah yang kemudian digunakan sebagai argumentasi untuk mengadakan perjanjian dan perundingan dengan pihak kolonial. ${ }^{49}$ Ini menunjukkan penerbitan karya tersebut digunakan untuk memenuhi kebutuhan keilmuan di kalangan istana. Perkembangan selanjutnya menunjukkan bahwa buku tersebut juga digunakan secara meluas di luar istana.

Uraian di atas menunjukkan bahwa karya-karya yang khusus membahas pemerintahan dan tata negara dalam sejarah Melayu sudah ada sejak abad ke-17. Hanya saja, setelah kejayaan kesultanan Melayu seperti kerajaan Selangor, Johor-Riau, dan juga kerajaan Terengganu kemudian tidak berhasil diteruskan sampai zaman sekarang. Akibatnya pandangan pemerintahan semata-mata hanya didapatkan dari peradaban benua lain. Sementara proses transkripsi serta penyaduran, demikian pula penerjemahan sudah berlangsung sejak itu. Tidak saja tiga hal tersebut. Bahkan para ulama yang berada dalam lingkungan kerajaan sudah menghasilkan karya sendiri yang merupakan buah pikiran orisinil sebagai hasil dari pengalaman sehari-hari. Sehingga cerminan budaya dan pemikiran yang berasal dari lingkungan alam Melayu kemudian akan lebih mudah dimaknai.

\section{G. Tantangan Pemerintahan di Negara-negara Muslim}

Ada kesadaran identitas yang tumbuh di kalangan dunia Islam. Mulai dari Afrika sampai ke Libanon dan juga mencapai semenanjung Asia Tenggara yang berujung di daratan Singapura. Beberapa negara, walaupun tidak mencantumkan dalam konstitusi sebagai negara Islam tetapi mayoritas penduduknya beragama Islam. Setiap pemerintahan di negara-negara tersebut berupaya untuk mengadopsi praktik keislaman tidak saja dalam skala ibadah 
tetapi mencakup sampai ke tata kelola pemerintahan. ${ }^{50}$ Penelitian Zulkifli menunjukkan bahwa setiap institusi keuangan di Malaysia sudah mengintegrasikan Dewan Syariah ke dalam struktur lembaga. Kemudian dilengkapi juga dengan adanya unit yang khusus menyelaraskan prinsip-prinsip syariah dengan pelaksanaan manajemen, termasuk dalam pelaporan, tanggung jawab dan keterbukaan." Esposito melihat bahwa di 55 negara yang berpenduduk muslim, satu-satunya keyakinan yang mempunyai akar kesejarahan dalam politik beserta dengan kebudayaan hanyalah Islam. Hanya saja, Islam dan politik tidak mempunyai bentuk yang kaku. ${ }^{52}$ Kesadaran itu kemudian berkembang dalam aktivitas sosial politik.

Bangunan relasi antara Islam dan politik menemukan bentuk yang tidak tunggal. Dalam sejarah peradaban Islam telah dipraktikkan berbagai model yang kesemuanya dapat dikatakan sebagai bentuk dari penjiwaaan terhadap nilai-nilai keislaman. Haynes mengemukakan bahwa agama-agama dunia telah menjadi penerjemahan makna keberagamaan. Agama telah memberikan pemaknaan terhadap fakta sosial. Demikian pula dalam konteks universal, agama juga menjadi spirit bagi keberlangsungan demokrasi. ${ }^{53}$ Sehingga masing-masing umat beragama memaknai iman dalam kehidupan sehari-hari dengan keberagaman. Pemaknaan demokrasi dan demokratisasi ini kemudian berkembang menurut pandangan nasional masing-masing. Bahkan kemudian pembentukan negarabangsa dipicu dengan pandangan adanya ikatan kesamaan kultural berdasarkan aspek kebangsaan. Justru dengan nasionalisme yang mengambil bentuk emosional dan kadang esktrem menimbulkan perselisihan tersendiri.

Sebagaimana pertentangan Pan-Malayan Islamic Party (PMIP) menentang United Malays Nationalist Organization (UMNO) secara sengit. Tuduhan yang dilancarkan adalah bagaimana partai yang berkuasa justru tidak

50 M. Tayeb, "Islamic Revival in Asia and Human Resources Management", dalam Employee Relation, Vol. 19, No. 4, (1997), hal. 352-364.

si Zulkifli Hasan, "A Survey on Shariah Governance Practices in Malaysia, GCC Countries and the UK", dalam International Joumal of Islamic and Middle Eastem Finance and Management, Vol. 4, No. 1, (2011), hal. 30-51. hal. 68 .

52 J. L. Esposito, Islam: The Straigh Path, (New York, NY: Oxford University Press, 1988),

${ }^{53}$ J. Haynes, Religion and Global Politics, (London: Longman, 1998). 
menjadikan Islam sebagai dasar perjuangan. Justru yang terlihat adalah dominasi politik. Tetapi Islam yang didengungkan hanya sebatas slogan. Nasionalisme dipandang sebagai manifestasi kesukuan, dimana sikap yang justru dalam Islam adalah sebuah celaan. ${ }^{54}$ Sebagaimana juga kelompok Islam menuduh bangsa kalangan nasionalisme lebih condong ke arah peninggalan kolonialisme. Sementara Islam dipandang oleh mereka sebagai pandangan hidup sekaligus sebagai ajaran yang memiliki kelengkapan yang sempurna. Sehingga Islam harus dijadikan sebagai sistem kemasyarakatan dan sekaligus sebagai sistem kenegaraan. Adapun sikap bagi yang mendukung nasionalisme justru melihat bahwa sikap muslim seperti ini adalah ajaran yang kaku dan tidak toleran. ${ }^{53}$ Pertentangan-pertentangan seperti ini jika dibiarkan secara terus menerus justru akan berakibat tidak sehat bagu pertumbuhan negara muslim. Sekaligus ada kegaduhan yang tidak produktif dalam perjalanan kebangsaan.

Awal abad ke-21 memberikan gambaran sebagaimana dinyatakan Huntington adanya gelombang demokratisasi. Ini dilakukan oleh beberapa negara yang rakyatnya memandang bahwa ada kekuasaan otoriter yang berkuasa. Fenomena ini diistilahkan The Third Wave Democratization in The Late Twentieth Century. Efek bola salju dalam perlawanan tersebut telah mampu meruntuhkan rezim-rezim yang otoriter. ${ }^{56}$ Menerjemahkan pendapat ini, Fukuyama justru melihat perluanya penguatan negara. Dengan istilah "lebih kecil namun lebih kuat" memberikan pesan bahwa kekuatan suatu negara tidaklah berdasar kepada kebesaran. Bahkan bisa saja sebuah negara kecil secara jumlah dan ukuran statistik yang lain tetapi secara kelembagaan mempunyai kapasitas dalam pertumbuhan ekonomi, jaminan keamanan, dll. Kesemuanya itu tidak memerlukan cakupan wilayah luas, namun justru berada dalam pentingnya

${ }^{54}$ Muhammad Abu Bakar, "Islam dan Nasionalisme pada Masyarakat Melayu Dewasa Ini", dalam Tradisi dan Kebangkitan Islam di Asia Tenggara, peny. Taufik Abdullah dan Sahorn Siddique, (Jakarta: LP3ES, 1988).

${ }_{55}$ Muhammad Isa Anshari, Islam dan Nasionalisme, (Bandung: ttp, 1969)

56 Samuel P. Huntington, The Third Wave Demorratization in the Late Twentieth Century, (Oklahoma: University of Oklahoma Press, 1991). 
negara yang sungguh-sungguh kuat dan efektif dalam lingkup fungsi negara yang terbatas. ${ }^{57}$

Perkembangan berikutnya adalah adanya kecenderungan privatisasi agama yang memperlihatkan menjauhnya agama dari kepentingan umum. Demikian pula adanya pertanyaan tentang kredibilitas agama. Selanjutnya ada juga pertanyaan tentang apa relevansi agama untuk kepentingan umat. Sementara Beyer menguraikan adanya keharusan agama untuk memberikan pelayanan dalam mendukung dan meningkatkan keyakinan beragama. Sekaligus memperluas implikasi agama di luar dari jangkauan territorial agama itu sendiri. Ini berarti bahwa agama harus berfungsi secara internal bagi umatnya dan juga memberikan solusi bagi masalah-masalah di luar agama secara formal. Konsepsi function dan performance yang diuraikan Bayer dalam melihat konsepsi realitas berdasarkan cara pandang agama. Terakhir, nilai-nilai komunal menjadi berbeda. Demikian pula Islam sebagai prinsip kehidupan. Basis differensial baru kemudian justru ditentukan oleh kemampuan ekonomi. Seperti nilai kepatuhan dan solidaritas berubah dalam bentuk yang lain dari yang sudah ada. Parameter kultural tidak lagi berlaku, yang dominan adalah ekonomi dan politik. ${ }^{58}$ Sehingga norma yang dianut dalain komunitas menjadi terukur dengan kepentingan ekonomi. Begitu pula pengaruh politik yang mendominasi aktivitas.

Tantangan yang dikemukakan di atas, menunjukkan bahwa Islam sebagai agama sekaligus sebagai doktrin politik harus dapat menjawab permasalahan kckinian yang ada. Justru dengan masalah-masalah yang ada, kemudian Islam maju dengan solusi yang aplikatif akan menjadi bukti bahwa sesungguhnya penolakan terhadap konsep Islam sebagai ajaran dalam pemerintahan akan ditolak dengan sendirinya. Namun demikian tentu tidak secara kaku kemudian hanya mengedepankan istilah budud atau syariah dalam arti semata-mata hukuman. Hasil penelitian tentang keberhasilan Malaysia menerapkan sistem perbankan syariah menunjukkan bahwa Islam dapat menjadi jalan keluar bagi masalah abad ini.

\footnotetext{
57 Francis Fukuyama, Memperkual Negara, Penerj. A. Zaim Rofiqi, Jakarta: Gramedia Pustaka Utama, 2004), hal. $155-158$.

58 Gordon Mathews, Global Culture/Individual Identity: Searcbing for Home in The Cultural Supermarket, (London: Routledge, 2000).
} 


\section{H. Islam dan Transformasi Tata Kelola}

Secara teologis, Islam merupakan kesempurnaan. Pada sisi lain, kesempurnaan ini harus dilanjutkan dalam bentuk-bentuk yang lebih operasional. Untuk itu, pelaksanaan secara implementatif kebijakan publik harus diwarnai dengan moralitas agama. Iman dalam bentuk abstrak tetapi perilaku baik dalam kehidupan personal maupun publik merupakan buah dari keimanan itu sendiri. ${ }^{59}$ Secara teologis, keesaan atau kesatuan mutlak berada pada wilayah akidah. Diperlukan penghayatan individual untuk memaknai keesaan Tuhan. Sehingga tidak ada kepercayaan terhadap kebendaan, kecuali kepada Yang Esa itu sendiri. Pada seorang hamba yang tercerahkan oleh iman, maka dalam proses dan keberadaan di masyarakat senantiasa akan mencerminkan iman yang difahami itu dalam keadaban sehari-hari. Tidak ada larangan, bahkan ini merupakan intipati ajaran untuk menyandingkan antara etika Islam dengan pembangunan sosial kemasyarakatan. Jika tidak dibarengi oleh moralitas keberagamaan itu, maka ambisi dan egosime akan mendorong manusia sampai kepada tahap ketamakan. Dengan demikian, justru Islam membentengi manusia dari feodalisme, monopoli dan patriarki yang justru merusak peradaban manusia itu sendiri.

Ada tiga hal yang senantiasa menjadi wacana religiusitas yang harus ditransformasi sehingga lebih bersifat tata kelola. ${ }^{60}$ Berikut dikemukakan beberapa hal yang berhubungan dengan tantangan tersebut. Pertama, tauhid. Konsep pengesaan Allah menjadi dasar pertama antara yang berislam dan tidak berislam. Di saat seorang manusia mengucapkan persaksian untuk mengesakan Allah, maka saat itu juga menghilangkan semua aspek kebendaan yang harus dijadikan sesembahan. Pernyataan syahadat mengandung konsekwensi individu. Jika setiap individu muslim kemudian konsisten menjalankan syahadat yang telah diikrarkan, maka ini akan menjadi pondasi manajemen dan pembangunan

${ }^{59}$ J. Mark Halstead, "Islamic Values: A Distinctive Framework for Moral Education?" dalam Joumal of Moral Education, Vol. 36, No. 3, (September, 2007), hal. 283 - 296.

${ }^{60}$ Muhammad, Islam, "Transformasi Sosial Ekonomi dan Public Civility", dalam Jumal Studi Agama Millab, Vol. XI, No. 2, (Februari: 2012), hal. $408-423$. 
yang berkelanjutan. ${ }^{61}$ Ketika mendasarkan diri pada prinsip ketuhanan, maka bukan berarti pembentukan negara dalam konsep teokrasi. Sebaliknya justru yang berjalan adalah nomokrasi. ${ }^{62}$ Dimana kedaulatan yang ada di tangan rakyat sepenuhnya berada dalam pada hukum Allah. Sehingga kedaulatan yang dimaknai, bukannya tidak terbatas. Melainkan ada hukum-hukum Allah yang kemudian membatasi nilai-nilai politik yang ditugaskan kepada manusia.

Kedua, keadilan. Surah al-Nisa ayat 135 menjadi dasar bagi wajibnya penegakan keadilan dalam semua aspek kehidupan. Termasuk dalam urusan pemerintahan dan juga aktivitas politik. Persoalan pokok yang harus terimplementasi adalah adanya kesamaan. Ini perlu dilihat dalam fungsi yang diemban, kemampuan dan tugas yang menjadi kewajiban. Dengan mendasarkan diri pada keadilan ini, jika itu disebut dengan demokrasi, maka akan menegakkan nilai-nilai demokrasi dalam kemajemukan masyarakat. Nurcholish Madjid ketika menguraikan makna khutbah Rasulullah dalam haji wada' justru melihat bahwa pesan utama yang ada adalah keadilan itu sendiri. Paling tidak ada lima hal yang dipesankan Rasulullah yaitu persamaan manusia, kewajiban melindungi jiwa dan kehormatan individu, pertanggungjawaban pribadi, latangan menindas dan ditindas, terakhir kesamaan timbal balik antara laki-laki dan perempuan. ${ }^{63}$ Oleh karena itu, menjadi tugas keumatan untuk menerjemahkan pesan-pesan Rasulullah dalam khutbah wada' menjadi realitas. Tidak sekedar konsep semata, tetapi teraplikasi dalam bentuk instrument masyarakat.

Ketiga, amanah dan tanggung jawab. Hakikat dan esensi spiritual kemanusiaan kemudian tugas kekhalifaan manusia yang diemban sebagai kontrak awal dengan Tuhan, maka tujuan akhirnya adalah tumbuhnya kedamaian di dunia. Maka jika tauhid dimaknai sebagai iman, maka ada akar kata yang sama antara iman dan amariah. Tugas menciptakan kedamaian dunia

6! Abu A'la al-Maududi, Khilafab cian Kerajaan, Muhammad al-Baqir (peneri.), (Bandung: Mizan, 1990), hal. 13.

${ }_{62}$ M. Tahir Azhary, Negara Hukum: Suatu Studi tentang Prinsipmya yang dilihat dari Segi Hukum Islam, Implementasinya pada Priode Negara Madinab dan Masa Kini, Jakarta: Bulan Bintang, 1992), hal. $64-65$.

${ }^{63}$ Nurcholish Madjid, dkk, Kebampaan Spiritual Masyarakat Moderen, Respond dan Transformasi Nitai-nilai Islam menuju Masjarakat Madani, Jakarta: Paramadina, 2005), hal. 40. 
yang menjadi tugas utama manusia dapat dijalankan jika memiliki turunan iman kemudian dilaksanakan dengan amanah untuk mewujudkan keamanan. Amanah bergandengan dengan adil. Pesan ayat 58 al-Quran [4] bahwa amanah hendak disampaikan kepada yang berhak. Masih dalam ayat yang sama bahwa adil harus menjadi prasyarat dalam pelaksanaan hukum. Prinsip syura, jika dipandang dalam wacana demokrasi sesungguhnya juga bersamaan dengan tanggungjawab. Tindakan tidak jujur, penyelewengan tanggung jawab yang mesti diarahkan kepada kemaslahatan ummat manusia. Saat berubah menjadi urusan memperkaya diri sendiri dan keluarga, maka saat itu juga mengubah kepercayaan masyarakat. Sementara rakyat dengan sepenuh hati dan jujur untuk meletakkan tuntutan kepada wakilnya dengan harapan ada amanah dan tanggung jawab yang senantiasa menaungi pelaksanaan tugas.

Ketiga prinsip yang diuraikan di atas, sesungguhnya sudah menjadi pandangan seorang muslim. Hanya saja, selama ini agama hanya digunakan sebagai alat legitimasi. Sekaligus diberdayakan untuk kepentingan politik jangka panjang. Agama seharusnya harus menjadi panduan agar senantiasa menjadi arah dan tujuan utama dalam pelaksanaan politik praktis. Tidak lagi sekedar menjadikan agama sebagai simbol untuk meraup suara tetapi dalam praktik yang ada simbol-simbol tidak tercermin dan teroperasionalkan dalam kehidupan sehari-hari. Hasil penelitian menunjukkan bahwa Islam sekaligus digunakan sebagai kelompok etnisitas. Jika menggunakan analisis Clifford Geertz, maka ini dianggap sebagai sesuatu yang hadir sebagai hasil yang given. ${ }^{64}$ Ada konstruksi sosial sejak lama sudah berproses. Dari kehidupan masyarakat ada hal yang menjadi modal spiritual sebagaimana dalam istilah Dsouli dkk. ${ }^{65}$ Kondisi ini kemudian akan menjadi kerangka dalam melihat keadaban etis sebuah masyarakat. Dimana nilai-nilai agama kemudian senantiasa menjadi pemicu kelangsungan dalam urusan keseharian.

\footnotetext{
${ }^{64}$ Clifford Geertz, The Interpretation of Cultures, (New York: Basic Books, 1973), hal. 273 277.

${ }^{65}$ Guarda Dsouli, Nadeem Khan, dan Nada K. Kakabadse, "Spiritual Capital The Coevolution of An Ethical Framework Based on Abrahamic Religious Values in the Islamic Tradition", dalam Joumal of Management Development, Vol. 31, No. 10, (2012), hal. 1058 - 1076.
} 


\section{Implikasi Teoritis}

Pandangan yang melihat bahwa perlu ada pemisahan antara agama dan negara sesungguhnya kurang lebih diilhami dari teori-teori dari abad pertengahan. Salah satu pandangan itu dikemukakan oleh John of Paris. Secara tegas menolak antara penyatuan keduanya. John melihat bahwa ada masyarakat yang terpisah dan merupakan pembeda. Walaupun juga diakui bahwa masingmasing kesatuan berasal dari Tuhan yang sama. Ada tujuan yang sama, tetapi kewenangan yang berbeda. Doktrin ini dikemukakan dalam "De Potestate Regia et Papali". Kesimpulannya John melihat bahwa gereja semata-mata berada dalam kekuasaan spiritual, bukan yang lain. ${ }^{66}$ Pada sisi lain, jika Islam dipandang oleh pemeluknya tidak saja sebagai sistem filsafat, maka Islam harus menjadi jalan hidup sebagai aturan yang yang lengkap dan komprehensif. Geertz menemukan bahwa dalam pandangan seorang muslim, agama tidak dapat memisahkan antara kehidupan dunia dan ibadah yang berseberangan. Tetapi justru keduanya adalah kesatuan dalam rangka mengintegrasikan antara individu dengan masyarakat. ${ }^{67}$ Pandangan John dan Geertz yang berbeda ditunjukkan dalam posisi yang berbeda pula. Jika menguarikan dalam kerangka menghindari adanya gesckan kepentingan. Sementara Geertz tampil alam bentuk ilmuwan yang mengabdi pada pengembangan ilmu.

Agama dapat dilihat sebagai elemen penting dalam politik. Walaupun juga kadang tidak dapat dibuktikan secara kuantitatif tetapi tidak dapat dipungkiri salah satu faktor yang mendorong merebaknya demokratisasi adalah agama itu sendiri. Hasil penelitian ini menunjukkan bahwa Malaysia mendayagunakan agama untuk mencapai kemajuan. Dimana di satu sisi meredam konflik antar agama tetapi lebih memilih untuk berdinamika dalam wacana keislaman. Justru dengan pilihan ini mebuktikan bahwa kemajuan dalam tata kelola pemerintahan dapat dicapai dengan adanya kesamaan prinsip. Terutama dalam menggunakan fondasi keberislaman sebagai tolok ukur utama. Jika mempergunakan teori Bidabad yang menyatakan bahwa komunitas agama 281.

${ }^{6}$ Riviere, Le Probleme de I' Egliseet de I'Etat an Temps de Pbillipe le Bel, (Louvain, 1926), hal.

${ }^{67}$ Clifford Geertz, Islam Observed: Religious Development in Morocco and Indonesia, (Chicago, II. University of Chicago Press, 1971), hal. 14. 
dapat saja mendapatkan keuntungarı dalain kepentingan nasional. ${ }^{6 b}$ Dengan kesamaan regulasi baik dalam pandangan individu, nasional maupun komunitas, maka akan lebih memudahkan untuk menunjukkan entitas yang sama untuk memperjuangkan kepentingan bersama atas nama nasionalisme. Maka dalam penelitian ini ditunjukkan bahwa Islam dalam kondisi politik Malaysia lebih memberikan keuntungan dalam pergaulan internasional dibandingkan aspek negatifnya. Sehingga dalam komunikasi untuk memperjuangkan isu tidak saja menggunakan perbedaan wilayah tetapi sekaligus juga merangkul kesamaan identitas keberagamaan.

Berbeda dengan lingkungan politik yang berada di Saudi Arabia. Justru Malaysia berhasil mengelola adanya perbedaan-perbedaan keluarga. Sehingga perbedaan yang ada kemudian dimasukkan dalam perlembagaan yang disebut dengan kesultanan. Sehingga adanya sultan di setiap negeri justru memungkinkan untuk memberikan dukungan bagi keberlangsungan negara. Sementara di Saudi Arabia, walaupun sama dengan Malaysia yang menganut sistem kerajaan tetapi Malaysia berhasil mengakomodasi kepentingan rakyat sehingga raja dan rakyat kemudian tetap mendapatkan masing-masing posisi yang menguntungkan secara politik. Adapun Saudi Arabia, hanya mempergunakan kekuasaan untuk keluarga di lingkungan clan tertentu. Sehingga gerakan fundamentalisme berkembang dengan mempergunakan identitas Islam. Partisipasi politik tidak dijalankan seiring dengan tuntutan demokratisasi. ${ }^{99}$ Sehingga Islam dan negara yang berjalan dalam politik Malaysia menjadi model tersendiri. Dimana Islam tidak ditunjukkan dengan kekuasaan kerajaan sematamata tetapi ada partisipasi, konstribusi dan juga interaksi rakyat. Sementara itu, kerajaan juga dibatasi dengan kewenangan dan kekuasaan tertentu yang dilembagakan.

Hasil penelitian menunjukkan bahwa partisipasi politik di Malaysia bersinergi dengan kekuasaan kerajaan. Ini menunjukkan bahwa pemerintahan

${ }^{68}$ Bijan Bidabad, "Public International Law Principles: an lslamic Sufi Approach", dalam Intemational Jowmal of Law and Management, Vol. 53, No. 6, (2011), hal. $393-412$.

69 Yeslam al-Saggaf dan Kenneth Einar Himma, "Political Online Communities in Saudi Arabia: the Major Players", dalam Journal of Infornation, Commmunication eo Etbics in Suciety, Vol. 6 . No. 2 (2008), hal. $127-140$. 
dapat mengelola kelas sosial yang ada. Maka, faktor Islam menjadi penting dalam melihat praktik ini. Nilai dan persepsi interpersonal tidak lagi menjadi kendala dengan penetapan Islam sebagai agama resmi. Walaupun sikap interpersonal ini adalah pandangan politik, tetapi eksistensi yang diterjemahkan dalam urusan politik tidak mendorong untuk membuat kelompok dengan nilai yang berbeda. Sebab sejak awal nilai yang dianut merupakan prinsip yang sama dengan apa yang diyakini kelompok lain. Maka, kondisi ini dalam pandangan Almond dan Verba akan memunculkan warga negara yang penuh percaya diri. Kcpercayaan terhadap kompetensi sesama warga negara adalah kunci sikap politik. Dengan tumbuhnya kepercayaan, maka dapat saja mendorong partisipasi. Selanjutnya akan terbentuk partisipasi aktif, kepuasan dalam bernegara serta menjadi warga negara yang setia. Pada giliran berikutnya akan mendorong wujudnya hubungan sosial dan kerjasama diantara warga negara. ${ }^{70}$ Faktor ini kemudian mengeliminasi wujudnya perbedaan-perbedaan ideology yang menjadi wacana. Jika tidak dikelola, akan menimbulkan kegaduhan. Tetapi dalam praktik Malaysia, justru berhasil meredam kegaduhan itu. Kemudian menjadikan energi untuk aksi positif.

Akhirnya, hasil penelitian ini menunjukkan bahwa ada transformasi dan juga penyesuaian akan ide demokratisasi. Ketika demokrasi kemudian berjalan dan berkembang, termasuk di negara bukan asal demokrasi itu sendiri, ada adaptasi dan akulturasi dengan budaya yang sebelumnya sudah ada. Prinsip pemerintahan berjalan sesuai dengan norma dan keyakinan yang dimiliki masing-masing negara. Demikian pula di Malaysia, dimana Islam sudah menemukan tempat kerika demokrasi belum memberikan ide dalam kelangsungan pemerintahan. Maka, ketika demokrasi dan relasi negara dengan agama mulai menjadi wacana, keberagaman dan keberagamaan yang sudah ada mengalami akulturasi. Fenomena ini deijelaskan Nasr bahwa sesungguhnya pelaksanaan pemerintahan dalam Islam sangatlah sederhana. Aturan fiqh sudah jelas menguraikan "apa yang boleh" dan "apa yang tidak boleh". Sehingga setiap muslim kemudian akan taat pada aturan dasar ini. Termasuk dalam kehidupan

\footnotetext{
${ }^{70}$ Gabriel A. Almond dan Sidney Verba, Budaya Politik, penerj. Sahat Simamora, (Jakarta: Bina Kasara, 1984), hal. $254-256$.
} 
politik. ${ }^{11}$ Untuk itu, penelitian ini menunjukkan bahwa tata kelola pemerintahan jika menggunakan prinsip dan semangat keberislaman secara mandiri akan memberikan sumbangsih bagi kemajuan kemanusiaan.

\section{J. Penutup}

Penelitian ini menunjukkan bahwa politik dan agama dalam pemerintahan Malaysia dapat berjalan seiring. Prinsip-prinsip Islam kemudian menjadi inspirasi dalam penetapan kebijakan. Termasuk di dalamnya bagaimana sistem perbankan syariah menjadi daya dukung perekonomian. Sementara dalam sistem pemerintahan dikelola dengan menggunakan pandangan politik Islam. Malaysia sebagai sebuah entitas bangsa dan negara kemudian berusaha mengadaptasi Islam untuk dijadikan standar etis dalam kenegaraan. Walaupun mendapatkan kritikan dari dalam Malaysia sendiri, tetapi ada beberapa yang sudah disepakati sejak awal ketika pendirian Malaysia sebagai sebuah negara. Ketidaksepakatan hanya pada beberapa hal yang menjadi agenda bersama. Tetapi dalam praktik yang sudah berjalan, justru syariah dan pelaksanaan kebebasan beragama justru menjadi dinamisator masyarakat.

Jika pandangan tertentu berusaha menjelaskan ketidaksinkronan untuk menetapkan agama dan negara secara bersamaan, maka dalam konteks Malaysia tidak lagi menjadi wacana. Justru agama dijadikan sebagai alat untuk melakukan transformasi di masyarakat. Sehingga dengan adanya keseragaman prinsip menjadikan kekuasaan dapat diarahkan untuk melayani kepentingan kemanusiaan. Tidak lagi hanya sekedar menjadi slogan semata-mata tetapi lebih dari itu bergerak kea rah penerjemahan makna politik sebagai alat. Kepercayaan politisi sejak awal untuk memilih Islam sebagai acuan utama menjadikan agama untuk menggerakkan sistem politik. Walaupun demikian, agama lain secara bebas tetap dapat dipraktikkan. Ini menunjukkan bahwa Islam sesungguhnya menjadi sebuah kesadaran kolektif masyarakat. Sehingga dapat saja menjadi lokomotif untuk sebuah perubahan.

${ }^{71}$ S. HAL. Nasr, The Heart of Iskam: Enduring Values for Humunity, (New York, NY: Harpo Collins, 2004), hal. 148. 


\section{DAFTAR PUSTAKA}

Ali, Muhammad Daud. 2002. Hukum Islam di Indonesia. cet. III. Jakarta: PT. Raja Grafindo Persada.

Al-Maududi, Abu A'la. 1990. Kbilafab dan Kerajaan, Muhammad al-Baqir (penerj.). Bandung: Mizan.

Al-Mawardi, Abu al-Hasan Ali. tt. al-Abkam al-Sulthaniyyah. Lebanon: Dar alFikr.

Almond, Gabriel A. dan Verba, Sidney. 1984. Budaya Politik, penerj. Sahat Simamora. Jakarta: Bina Kasara.

Al-Saggaf, Yeslam. dan Himma, Kenneth Einar. 2008. "Political Online Communities in Saudi Arabia: the Major Players". dalam Joumal of Information, Commmunication \& Ethics in Society. Vol. 6. No. 2. 127 - 140.

Anshari, Muhammad Isa. 1969. Islam dan Nasionalisme. Bandung: ttp.

Arifin, Mohammad bin. 1999. Islam dalam Perlembagaan Persekutuan. dalam Ahmad Ibrahim, dkk. Perkembangan Undang-undang Perlembagaan Persekutuan. Kuala Lumpur: Dewan Bahasa dan Pustaka.

Arkoun, Mohammed. 2001. Islam Kontemporer: Menuju Dialog Antar-agama. Yogyakarta: Pustaka Pelajar.

Azhary, M. Tahir. 1992. Negara Hukum: Suatu Studi tentang Prinsipnya yang dilihat dari Segi Hukum Islam, Implementasinya pada Priode Negara Madinab dan Masa Kini. Jakarta: Bulan Bintang.

Azra, Azyumardi. 1994. "Kata Pengantar". dalam Bernard, Babasa Politik Islam. penerj. Ihsan Ali Fauzan. Jakarta: Gramedia.

Baali, Fuad dan Wardi, Ali. 1989. Ibn Khaldun dan Pola Pemikiran Islam. terj. Mansuruddin. Jakarta: Pustaka Firdaus.

Bacha, Obiyathulla Ismath. 2008. "The Islamic Interbank Money Market and a Dual Banking System: the Malaysian Experience". International Joumal of Islamic and Middle Eastem Finance and Management. Vol. 1. Iss: 3. 210 226.

Badawi, Tsarwat. 1998. al-Nushum al-Siyasab. Juz I. Lebanon: Dar al-Fikr. 
Bakar, Muhammad Abu. 1988. "Islam dan Nasionalisme pada Masyarakat Melayu Dewasa Ini". dalam Tradisi dan Kebangkitan Islam di Asia Tenggara. peny. Taufik Abdullah dan Sahorn Siddique. Jakarta: LP3ES.

Bellah, Robert N. 1975. The Broken Covenant: American Civil Religion in a Time of Trial. New York: Seabury.

Benson, K.L. Brailsford, T.J. dan Humphrey, J.E. 2006. "Do socially responsible fund managers really invest differently?". dalam Journal of Business Ethics. Vol. 65. 337-57.

Bidabad, Bijan. 2011. "Public International Law Principles: an Islamic Suft Approach", dalam International Joumal of Law and Management. Vol. 53. No. 6. $393-412$.

Bryman, A. 1988. Quantity and Quality in Social Research. London: Unwin Hyman. Buang, Ahmad Hidayat. 2003. Kebebasan Memberi Pandangan dalam Isu-isu Agama Islam: Kajian terhadap Fatwa-fatwa Jabatan Mufti Negeri-negeri di Malaysia. Makalah dalam Seminar Pemikiran Islam Peringkat Kebangsaan I di Akademi Pengajian Islam, Universiti Malaya. 11 Januari.

Carcyle, R. W. dan J, A. 1928. A History of Medieval Political Theory in The West, Vol. 5. London: Blackwood.

Cook, Bradley J. dan Stathis, Michael. 2012. "Democracy and Islam: Promises and Perils for the Arab Spring Protests". dalam Joumal of Global Responsibility. Vol. 3, No. 2. $175-186$.

Dsouli, Guarda. Khan, Nadeem. dan Kakabadse, Nada K. 2012. "Spiritual Capital The Co-evolution of An Ethical Framework Based on Abrahamic Religious Values in the Islamic Tradition". dalam Joumal of Management Development. Vol. 31. No. 10. 1058 - 1076.

Effendy, Bahtiar. 2003. Islam and The State in Indonesia. Singapura: ISEAS.

Esposito, J. L. 1988. Islam: The Straigh Path. New York, NY: Oxford University Press.

Esposito, John L. 1990. Islam dan Politik. Jakarta: Bulan Bintang. Federal Constitution. 2002. Kuala Lumpur: International Law Book Service. Friedrich, Carl J. 1963. Man and His Government, An Empirical Theory of Politics. New York: Mc Graw Hill Book Coy, Inc. 
Fukuyama, Francis. 2004. Memperkuat Negara. Penerj. A. Zaim Rofiqi. Jakarta: Gramedia Pustaka Utama.

Geertz, Clifford. 1971. Islam Observed: Religious Development in Morocco and Indonesia. Chicago, IL: University of Chicago Press.

Geertz, Clifford. 1973. The Interpretation of Cultures. New York: Basic Books. 273 $-277$.

Gibb, I. A. R. (peny.). 1932. Whither Islam? A Survey of Modern Movements in the Moslem World. London: Victor Gollancz Ltd.

Glock, Charles Y. 1972. "Images of God, Images of Man, and The Organization of Social Life". dalam Journal for the Scientific Study of Peligion. No. 11.1-15.

Halstead, J. Mark. 2007. "Islamic Values: A Distinctive Framework for Moral Education?", dalam Joumal of Moral Education. Vol. 36. No. 3. September. $283-296$.

Harun, Jelani 2003. Pemikiran Adab Ketatanegaraan Kesultanan Melayu. Kuala Lumpur: Dewan Bahasa dan Pustaka.

Hasan, Zulkifli. 2011. "A Survey on Shari'ah Governance Practices in Malaysia, GCC Countries and the UK". dalam International Joumal of Islamic and Middle Eastern Finance and Management. Vol. 4. No. 1. 30-51.

Hasyim, Junaidah. 2009. "Islamic Revival in Human Resources Management Practices among Selected Islamic Organisations in Malaysia". dalam Joumal of Islamic and Middle Eastern Finance and Management. Vol. 2. No. 3. 251-267.

Haynes, J. 1998. Religion and Global Politics. London: Longman.

Hitt, Philip K. 1990. History of The Arab. London: Macmillan.

Hokker, M. B. Islamic Law in South-East Asia, (Kuala Lumpur: Oxford University Press, 1984.

Huntington, Samuel P. 1991. The Third Wave Democratization in the Late Twentieth Century. Oklahoma: University of Oklahoma Press.

Ibrahim Abu Bakar, Islamic Modernism in Malaya, The Life and The Though of Sayyid Syaykh al-Hadi 1867-1934, (Kuala Lumpur: University of Malaya Press, 1994. 
Islam, Muhammad. 2012. "Transformasi Sosial Ekoromi dan Public Civility". dalam Jurnal Studi Agama Millah. Vol. XI. No. 2. Februari. 408 - 423.

Leege, David C. 1987. The Parish as Community, Notre Dame Siudy of Catbolic Parish Life, Report 10. Notre Dame, IN: University of Notre Dame.

Maarif, Ahmad Syafii. 1983. Islam as the Basis of State: A Study of the Islamic Political Ideas as Reflected in the Constituent Assembly Debates in Indonesia. Disertasi. Chicago: University of Chicago.

Madjid, Nurcholish. 1990. "Kata Sambutan" dalam Munawir Syadzali, Islam dan Tata Negara: Ajaran, Sejarah dan Pemikiran. Jakarta: UI-Press.

Madjid, Nurcholish. dkk. 2005. Kehampaan Spiritual Masyarakat Moderen, Respond dan Transformasi Nilai-nilai Islam menuju Masyarakat Madani. Jakarta: Paramadina.

Mahdi, Muhsin. 1971. Ibn Kbaldun's Philosopby of History, A Study in the Pbilosophy Foundation of the Science Culture. Chicago: University Press.

Majid, Mahmood Zuhdi Abd.. Bidang Kuasa Mabkamah Syariab di Malaysia, (Kuala Lumpur: Dewan Bahasa dan Pustaka, 1997), hal. 103.

Malaysian Statistics Department. 2006. Malaysian Population Survey. Kuala Lumpur: Malaysian Government.

Mathews, Gordon. 2000. Globai Culture/Individual Identity: Searching for Home in The Cultural Supermarket. London: Routledge.

Mehden, Fred R. von der. 1957. Islam and the Rise of nationalism in Indonesia. Disertasi. Berkeley: University of California Berkeley.

Muhadjir, Noeng. 1996. Metodologi Penelitian Kualitatif. Yogyakarta: Rake Sarasin.

Mulia, Musdah. 2001. Negara Islam: Pemikiran Politik. Husain Haikal. Jakarta: Paramadina.

Nakhaie, Ahmad. 2001. Jibad Guru Agama dalam Pembangunan Bangsa Melayu dan Pembentukan Negara Islam Maju. makalah disampaikan dalam Kuruss Khas Perdana (Pendidikan Islam), 22 Mei. Kuala Lumpur.

Napi, Wan Kamal Wan 2007. The Islamization Of Politics In Malaysia: How Religious Political Opportunities and Threats Influence Religious Framing and Counterframing. Disertasi. Carbondale: Southern Illinois University, 
Nasr, S. H. 2004. The Heart of Islam: Enduring Values for Humanity. New York, NY: Harper Collins.

Nasution, S. 1996. Metode Penelitian Naturalistik Kualitatif. Bandung: Tarsito.

Nata, Abuddin. 1999. Metodologi Studi Islam. cet. III. Jakarta: PT. RajaGrafindo Persada.

Natsir, Mohamed. 1951. "Agama dan Negara”. dalam M. Isa Anshary. Falsafah Perjuangan Islam. Medan: Penerbit Saiful.

Olesen, Asta. 1996. Islam and Politics in Afghanistan. Curzon Press: St. John's Studios, Church Roadl Richmond, Surrey.

Osman, Fathi. 1983. "Patameters of the Islamic State". Arabia. The Islamic World Review. No. 17. Januari.

Qaedhawi, Yusuf. 1997. Min Figh al-Daulah fi al-Islam. Kairo: Dar al-Syuruq. Riviere. 1926. I e Probleme de I' Egliseet de I'Etat au Temps de Phillipe le Bel. Louvain. Saward, Michael. 1996. "Democracy and Competing Values", dalam Govermment and Opposition, Vol. 31, No. 4. 467-86.

Soekanto, Sourjono. 1973. Pengantar Sosiologi Hukum. Jakarta: Bharata.

Strauss, Anselm dan Corbin, Juliet. 2003. Dasar-dasar Penelitian Kualitatif: Tatalangkah dan teknik-teknik. Teoritisasi Data. Yogyakarta: Pustaka Pelajar.

Surur, Taha Abd al-Baqi. Dawla al-Quran, (Kairo: Dar al-Nadha Misr, 1972), hal $8 \mathrm{G}$.

Susilawetty. 2008. "Implementasi Ketentuan Hukum Waris Islam Indonesia dan Malaysia", dalam Jumal Reformasi Hukum. Vol. XI. No. 2. Desember. 130- 149.

Syarif, Zalila dan Ahmad, Jamilah Haji. 1993. Kesusasteraan Melayu Tradisional. Kuala Lumpur: Dewan Bahasa dan Pustaka.

Tayeb, M. 1997. "Islamic Revival in Asia and Human Resources Management". dalam Employee Relation. Vol. 19. No. 4. 352-364.

Thaib, Lukman. 2005. Islamic Political Representation in Malaysia. Kuala Lumpur: University of Malaya Press. 202-203.

Wald, Kenneth D. 1992. Religion and Politics in the United States. Washington DC: Congressional Quarterly Press. 
Wan Zahidi Wan Teh. 2000. Malaysia Daulah Islamiah. Makalah disampaikan perjumpaan YAB Perdana Menteri bersama Pegawai-pegawai Agama Islam seluruh Malaysia. 28 - 29 Agustus. Putrajaya: JAKIM.

Yahaya, Azlan R. 2012. Islam Hadhari: An Ideological Discourse Analysis of Selected Speeches by UMINO President and Malaysia Prime Minister Abdullab Abmad Badawi. Disertasi. Amerika Serikat: Scripps College of Communication of Ohio University.

Zainuddin, A Rahman. 1992. Kekuasaan dan Negara Pemikiran Politite Ibnu Khaldun. Jakatra; PT. Gramedia.

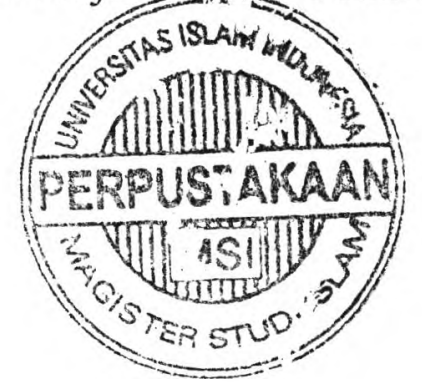

